\title{
On the Synthesis of CMD from Manganese-Ammonium-Carbamate and its Properties IV. Heating Properties of Densified CMD and Application of Its Dehydrated Product to $\mathrm{Li}-\mathrm{MnO}_{2}$ Cells*
}

\author{
Nobuaki MiYAmoto**, Hidehiko KIDO** and Isao TANABE***
}

\begin{abstract}
The heating and dehydration properties in both air and $\mathrm{O}_{2}$ atmosphere for densified CMD were compared with those of EMD, and the discharge properties and packing capabilities of these dehydrated products for $\mathrm{Li}-\mathrm{MnO}_{2}$ cells were investigated as follows. 1) In the DTA tests, the peak indicative of conversion to $\mathrm{Mn}_{2} \mathrm{O}_{3}$ shifted to a higher temperature by about $30^{\circ} \mathrm{C}$ in $\mathrm{O}_{2}$ atmosphere (at $560^{\circ} \mathrm{C}$ ) than in air for both CMD and EMD, and the dehydrated products in $\mathrm{O}_{2}$ atmosphere had slightly higher $\mathrm{MnO}_{2}$ content and hydrazine index than did those in air. In $\mathrm{O}_{2}$ atmosphere, this might be attributable to the suppression of decomposition of $\mathrm{MnO}_{2}$ on dehydration. 2) For both CMD and EMD, the optimum dehydration temperature was found to be about $380^{\circ} \mathrm{C}$ by the discharge tests. The dehydrated products obtained in $\mathrm{O}_{2}$ atmosphere were shown to be superior in discharge properties to those of the products obtained in air. 3) The dehydrated CMD whose $\mathrm{MnO}_{2}$ ratio by chlorate reaction was 22\% showed higher tapping density, packing capability and discharge properties compared with those of $\mathrm{EMD}$ as the cathode material in $\mathrm{Li}-\mathrm{MnO}_{2}$ cells.
\end{abstract}

\section{Introduction}

In recent years, the dehydration properties of electrolytic manganese dioxide (EMD) and application of its dehydrated product to $\mathrm{Li}$ $\mathrm{MnO}_{2}$ cells have been investigated by Ikeda et $a l^{1)}$ and Hirai et $a l^{2,3)}$. However, our survey of the literature showed that the heating properties of CMD, the properties of its dehydrated product and its application to $\mathrm{Li}-\mathrm{MnO}_{2}$ cells have not yet been studied. In our preceding papers, the synthesis of dense $\mathrm{MnCO}_{3}$ from $\mathrm{Mn}-\mathrm{NH}_{4}-$ carbamate $^{4)}$, its oxidation ${ }^{5)}$ and the densification of crude $\mathrm{MnO}_{2}{ }^{62}$ were described. This paper describes the heating property of densified CMD, the properties of the dehydrated product, the packing capability and discharge properties in $\mathrm{Li}-\mathrm{MnO}_{2}$ cells utilizing dehydrated $\mathrm{CMD}$, and the comparison of these properties with those of EMD. For both CMD and EMD, their heating properties in both air (used conventionally) and oxygen were compared each other. The reaction of conversion to $\mathrm{Mn}_{2} \mathrm{O}_{3}$ occurred at a higher temperature by about $30^{\circ} \mathrm{C}$ in oxygen than in air, showing a

* Presented at 21 st Battery Symposium, Okayama, November, 1980.

** Ariake Technical College (150, Higashi-hagio, Omuta, Fukuoka)

*** The Technological University of Nagaoka (1603-1, Nagamine, Kamitomioka, Nagaoka, Nigata)

Key Words: Densified CMD, Heating Property, Dehydrated Product, $\mathrm{Li}-\mathrm{MnO}_{2}$ Cells greater contribution of oxygen atmosphere to the quality of the dehydrated products. The effect of oxygen atmosphere on both the quality of the dehydrated products and the discharge properties was investigated in detail. Discharge tests of coin type $\mathrm{Li}-\mathrm{MnO}_{2}$ cells having these dehydrated $\mathrm{MnO}_{2}$ material as cathode were performed.

\section{Experimental}

\subsection{CMD and EMD samples}

As shown in Table 1, densified CMD samples were chosen and IC-1 (No. 7) was selected as the EMD sample. The No. 1 sample was obtained by further oxidation (in $3 \mathrm{~atm}$ wet $\mathrm{O}_{2}$ ) of crude $\mathrm{MnO}_{2}$ previously obtained by oxidation of dense $\mathrm{MnCO}_{3}$ in wet air. No. $2 \sim 6$ samples having various degree of densification were obtained by chlorate reaction of the No. 1 sample.

\subsection{Heating property and dehydration treatment}

Both DTA and TG were performed up to $600^{\circ} \mathrm{C}$ at a heating rate of $5^{\circ} \mathrm{C} / \mathrm{min}$ in both air and oxygen atmosphere to evaluate the difference in their heating properties. Samples in this experiment include the lightest CMD (No. 1 sample which was not subjected to the densification Process), the densest CMD (No. 6) and EMD (No. 7). A $20 \mathrm{~g}$ sample was heated in an electric furnace at $200^{\circ} \mathrm{C}$ to $420^{\circ} \mathrm{C}$ for $4 \mathrm{~h}$ 
Table 1 Densified CMD by chlorate reaction

\begin{tabular}{c|c|c|c|c|c|c|c|c|c|c}
\hline Kind & No. & $\begin{array}{c}\mathrm{MnO}_{2} \\
(\%)\end{array}$ & $\begin{array}{c}\mathrm{MnO}_{2} \text { ratio } \\
\text { by chlorate } \\
\text { reaction to } \\
\text { total } \mathrm{MnO}_{2}\end{array}$ & H.I. & $\begin{array}{c}\text { B.D. } \\
\mathbf{g} / \mathrm{cm}^{3}\end{array}$ & $\begin{array}{c}\text { T.D. } \\
\mathbf{g} / \mathrm{cm}^{3}\end{array}$ & $\begin{array}{c}\text { True. D. } \\
\mathbf{g} / \mathbf{c m}\end{array}$ & $\begin{array}{c}\text { Water } \\
\text { adsorp. } \\
(\%)\end{array}$ & $\begin{array}{c}\text { Ion exchange } \\
\text { cap. } \mathbf{Z}^{2+} \\
\times 10^{-5} \mathrm{~mol} / \mathbf{g}\end{array}$ & $\begin{array}{c}\text { Surf. A. } \\
\mathrm{m}^{2} / \mathbf{g}\end{array}$ \\
\hline \multirow{6}{*}{$\mathrm{CMD}$} & 1 & 91.0 & 0 & 57.2 & 1.53 & 1.74 & 4.69 & 38.5 & 35.5 & 57.4 \\
& 2 & 92.4 & 12.2 & 58.6 & 1.74 & 2.07 & 4.74 & 27.5 & 45.3 & 54.6 \\
& 3 & 92.2 & 20.5 & 57.9 & 1.92 & 2.25 & 4.71 & 24.5 & 42.5 & 48.5 \\
& 4 & 92.3 & 22.1 & 57.5 & 2.00 & 2.30 & 4.70 & 22.8 & 39.7 & 44.1 \\
& 5 & 92.3 & 24.6 & 56.5 & 2.06 & 2.42 & 4.65 & 20.2 & 38.0 & 39.2 \\
& 6 & 92.3 & 27.5 & 55.9 & 2.13 & 2.43 & 4.65 & 19.2 & 37.8 & 38.0 \\
\hline $\mathrm{EMD}$ & 7 & 91.1 & - & 56.2 & 1.49 & 2.32 & 4.46 & 19.2 & 37.1 & 58.5 \\
\hline
\end{tabular}

in both air and oxygen which were dried in $\mathrm{Mg}\left(\mathrm{ClO}_{4}\right)_{2}$, at a flow rate of $15 \mathrm{~L} / \mathrm{h}$. The residual water content in the dehydrated products at $110^{\circ} \mathrm{C}$ was determined by absorbing the water released at $750^{\circ} \mathrm{C}$ by $\mathrm{Mg}\left(\mathrm{ClO}_{4}\right)_{2}$ in $\mathrm{N}_{2}$ as the carrier gas. The $\mathrm{MnO}_{2}$ content and apparent density of the dehydrated products were determined in accordance with JIS, the hydrazine index (H.I.) by the Drotschmann") method, and the specific surface area by the BET process.

2.3 Shaping and packing capability of cathode mix utilizing the dehydrated products

As shown in the standard mixing ratio(CMD1 and EMD-1) in Table 2, dehydrated $\mathrm{MnO}_{2}$, acetylene black (A.B.), graphite and Teflon powder were thoroughly mixed together; a 250 mg sample weighed accurately was pressed into a cylindrical shape $17.2 \mathrm{~mm}$ in diameter at a pressure of $500 \mathrm{~kg} / \mathrm{cm}^{2}$ and dried in vacuo at $120^{\circ} \mathrm{C}$. The thickness of the shaped product was measured. The electrolyte was $1 \mathrm{M} \mathrm{LiClO}_{4}$, which was dried in vacuo at $120^{\circ} \mathrm{C}$ and dissolved in propylene carbonate which had been dehydrated by passage through a molecular sieve.
The absorption ratio of electrolyte in the cathode mix was measured; the cathode mix was immersed in the electrolyte for 5 hours and weighed after the solution adhering to its surface was wiped off with dry filter paper.

\subsection{Discharge tests}

As shown in Fig. 1, a test cell was made of nickel-plated brass with an effective electrode area of $2.3 \mathrm{~cm}^{2}$ and was screwed into the framework. The discharge tests were carried out in a dried argon atmosphere at $20 \pm 1^{\circ} \mathrm{C}$, using the cathode mix in Table2. The lithium

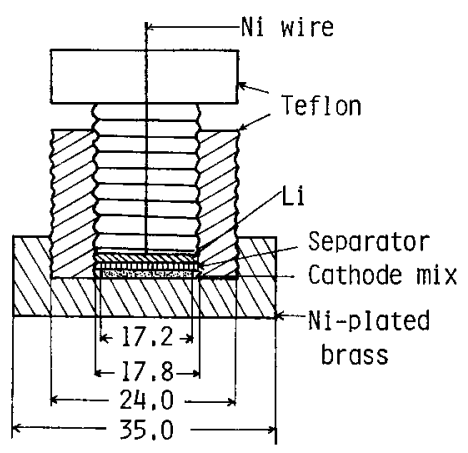

Fig. $1 \mathrm{Li}-\mathrm{MnO}_{2}$ cell used for the experiment

Table 2 Composition of the cathode mix of CMD $\left(22 \% \mathrm{MnO}_{2}\right.$ by chlorate reaction to total $\mathrm{MnO}_{2}$ ) and EMD

\begin{tabular}{c|c|c|c|c|c|c}
\hline Kind & $\begin{array}{c}\text { Combina- } \\
\text { tion No. }\end{array}$ & $\begin{array}{c}\mathrm{MnO}_{2} \\
(\mathrm{mg})\end{array}$ & $\begin{array}{c}\text { A.B. } \\
(\mathrm{mg})\end{array}$ & $\begin{array}{c}\text { Graphite } \\
(\mathrm{mg})\end{array}$ & $\begin{array}{c}\text { Teflon } \\
(\mathrm{mg})\end{array}$ & $\begin{array}{c}\text { Thickness of } \\
\text { pressed cathode } \\
\text { mix (mm) }\end{array}$ \\
\hline \multirow{3}{*}{$\mathrm{CMD}$} & 1 & $175(70)$ & $18.8(7.5)$ & $18.8(7.5)$ & $37.5(15)$ & 0.565 \\
& 2 & $186.4(70)$ & $20.0(7.5)$ & $20.0(7.5)$ & $39.9(15)$ & 0.60 \\
& 3 & $175(70)$ & $20.6(8.2)$ & $20.6(8.2)$ & $37.5(15)$ & 0.595 \\
\hline EMD & 1 & $175(70)$ & $18.8(7.5)$ & $18.8(7.5)$ & $37.5(15)$ & 0.60 \\
\hline
\end{tabular}

( ) : ratio 
electrode of about $1 \mathrm{~mm}$ thickness (about $0.12 \mathrm{~g}$ ), as the anode material, was made of $\mathrm{Li}$ metal (99.9\% purity, Rare Metallic Co.). The duration times of discharge down to $1.5 \mathrm{~V}$ at from 0.025 to $0.5 \mathrm{~mA} / \mathrm{cm}^{2}$ were measured and the discharge efficiencies were calculated.

\section{Results and Discussion}

\subsection{Heating properties and the effect} of oxygen atmosphere on the properties of the dehydrated products

Figures 2 and 3 show the resuls of $\mathrm{TG}$ and DTA in both air and oxygen for CMD No. 1, CMD No. 6 and EMD No. 7. It was noted that the temperature indicative of the conversion to $\mathrm{Mn}_{2} \mathrm{O}_{3}$ for both CMD and EMD shifted to the higher side by about $30^{\circ} \mathrm{C}$ in an oxygen atmosphere (at about $560^{\circ} \mathrm{C}$ ) compared to that

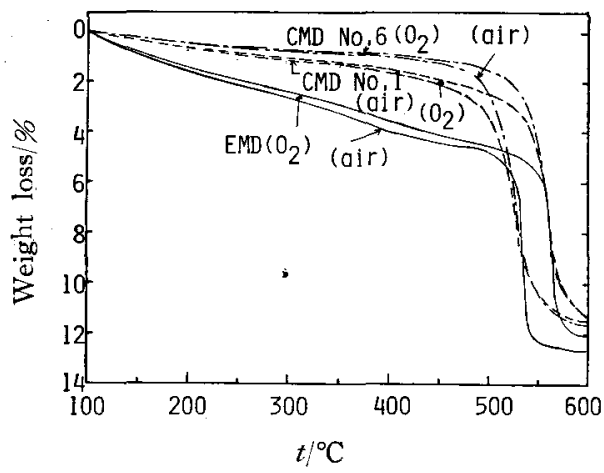

Fig. 2 Results of TG on both CMD and EMD in both dry air and dry $\mathrm{O}_{2}$

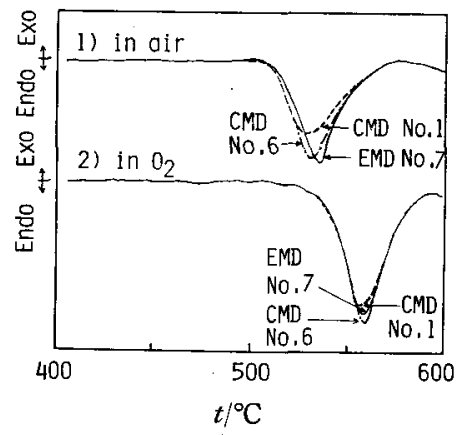

Fig. 3 Results of DTA on both CMD and EMD in both dry air and dry $\mathrm{O}_{2}$

in air, indicating the more favorable contribution of oxygen to their heat stability.

The dehydration temperature used convent- ionally ${ }^{1)}$ for $\mathrm{MnO}_{2}$ in $\mathrm{Li}-\mathrm{MnO}_{2}$ cells was $350 \sim$ $400^{\circ} \mathrm{C}$. A part of the $\mathrm{MnO}_{2}$ was considered to decompose in view of the difference in both the $\mathrm{MnO}_{2}$ content and the weight between before and after dehydration. Therefore, it was confirmed that the oxygen atmosphere suppressed the decomposition of $\mathrm{MnO}_{2}$.

The dehydration of both CMD and EMD at from $200^{\circ} \mathrm{C}$ to $420^{\circ} \mathrm{C}$ was performed in both air and oxygen, and the residual water content, the $\mathrm{MnO}_{2}$ content of the dehydrated products as well as the hydrazine index were determined.

The residual water content corresponding to each dehydration temperature are shown in Fig. 4. Although the residual water content in EMD is more than that of CMD at room temperature, it became almost the same as that of the dehydrated CMD obtained by treatment above $200^{\circ} \mathrm{C}$ for $4 \mathrm{~h}$; it amounted to $0.5 \sim 0.6 \%$ at $380^{\circ} \mathrm{C}$ and dropped down to $0.35 \%$ at $420^{\circ} \mathrm{C}$.

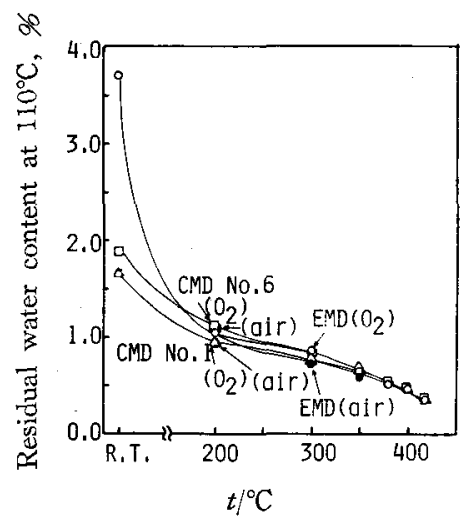

Fig. 4 Relation between dehydration temperature and residual water content at $110^{\circ} \mathrm{C}$

The variations in $\mathrm{MnO}_{2}$ content and hydrazine index due to the dehydration temperature are shown in Fig. 5. For both CMD and EMD, the $\mathrm{MnO}_{2}$ content of the dehydrated products in oxygen atmosphere was higher than that obtained in air by $0.3 \sim 0.7 \%$, its difference increasing with the increase in dehydration temperature. It was noted that the $\mathrm{MnO}_{2}$ content of EMD increased much more than that of CMD. The decrease in hydrazine index with the increase in dehydration temperature was especially significant for EMD in both cases. For both CMD and EMD, both the $\mathrm{MnO}_{2}$ content and the hydrazine index of the 
dehydrated products obtained in oxygen atmosphere were a little higher than those of the products obtained in air.

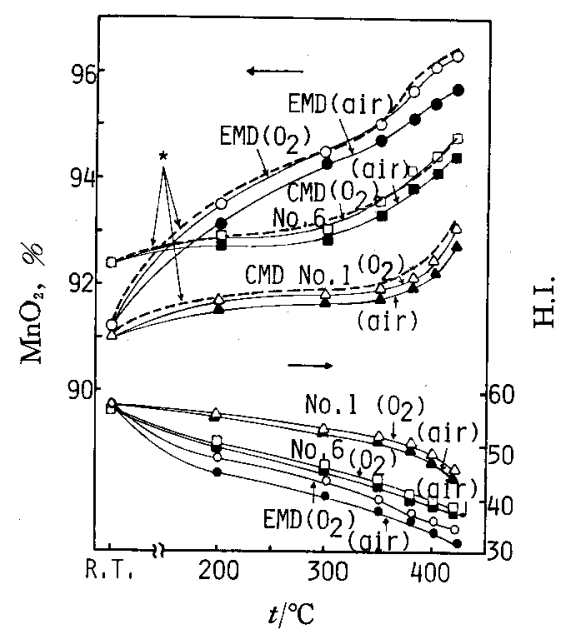

Fig. 5 Relation between dehydration temperature and both $\mathrm{MnO}_{2}$ content and H.I. of the dehy. drated products

*Calculated $\mathrm{MnO}_{2} \%$ from wt. loss by heating

The higher $\mathrm{MnO}_{2}$ content and hydrazine index of the dehydrated products in oxygen as compared to air might be attributable to the suppression of decomposition of $\mathrm{MnO}_{2}$ in the course of the dehydration. The difference in hydrazine index between the dehydrated products of both CMD and EMD might be mainly attributable to the significant difference in the specific surface area of the dehydrated products.

\subsection{The degree of densification of CMD, properties and packing capability of its dehydrated products}

Dehydration was performed in oxygen atmosphere at $380^{\circ} \mathrm{C}$, the optimum dehydration temperature as described later, for samples No. $1 \sim$ No. 6 in Table 1 . The variation in $\mathrm{MnO}_{2}$ content, residual water content and hydrazine index of the dehydrated products due to $\mathrm{MnO}_{2}$ ratio by chlorate reaction to total $\mathrm{MnO}_{2}$ are shown in Fig. 6. For various $\mathrm{MnO}_{2}$ ratios by chlorate reaction to total $\mathrm{MnO}_{2}$, Fig. 7 shows the tapping density of the dehydrated products, the thickness of the cathode mixes having a standard mixing ratio and absorption ratio of electrolyte in cathode mix.

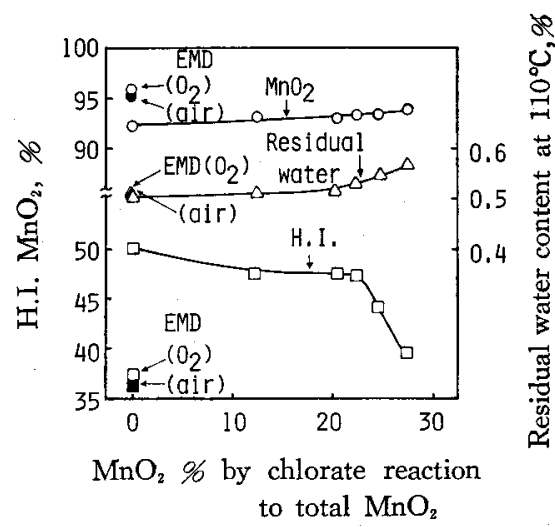

Fig. 6 Relation between $\mathrm{MnO}_{2}$ ratio by chlorate reaction to total $\mathrm{MnO}_{2}$ and properties of the dehydrated products (in $\mathrm{O}_{2}$ atmosphere for $4 \mathrm{~h}$ at $380^{\circ} \mathrm{C}$ )

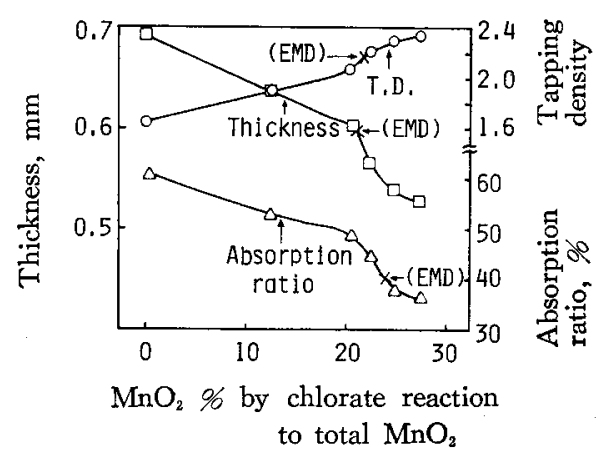

Fig. 7 Effect of $\mathrm{MnO}_{2}$ ratio by chlorate reaction to total $\mathrm{MnO}_{2}$ on T.D. of the dehydrated products at $380^{\circ} \mathrm{C}$, thickness and absorption ratio of electrolyte in cathode mix after pressing(Cathode mix : Mix ratio was CMD-1 and EMD-1 in Table 2)

The slightly higher $\mathrm{MnO}_{2}$ content of the dehydrated products of EMD compared to those of CMD might be due to the larger weight loss of EMD during dehydration. The hydrazine index decreased considerably with increasing $\mathrm{MnO}_{2}$ ratio by the chlorate reaction when the ratio was above $23 \%$; whereas, it decreased slightly when the ratio was below $22 \%$. Therefore, it is considered that the dehydrated products, whose $\mathrm{MnO}_{2}$ ratio by the chlorate reaction is above $23 \%$, have undesirable discharge properties in $\mathrm{Li}-\mathrm{MnO}_{2}$ cells. It was 
observed that the apparent density of the dehydrated product of CMD was larger than that of EMD when the $\mathrm{MnO}_{2}$ ratio by the chlorate reaction to total $\mathrm{MnO}_{2}$ was above $22 \%$. It might be due to the smaller weight loss of CMD compared with EMD in the dehydration process. The thickness of the cathode mix utilizing the dehydrated $\mathrm{CMD}$ in the case of the $22 \%$ ratio was considerably smaller compared with that of EMD due to the higher compression ratio of CMD. The absorption ratio of the cathode mix utilizing the dehydrated CMD (22\% ratio) was almost the same as that of EMD.

\subsection{Crystal structure of the dehydrated products}

The X-ray patterns of the dehydrated products for both CMD (No. 4 in Table 1) and EMD (No. 7) are shown in Fig. 8. EMD exhibited the $r$-type peak at $200^{\circ} \mathrm{C}$, a broad pattern similar to that of $\mathrm{CMD}$ (No. 1 in Table 1 at room temperature) at $300^{\circ} \mathrm{C}$, the $\beta$ type peak at $350^{\circ} \mathrm{C}$, and a higher $\beta$-type peak at $380^{\circ} \mathrm{C}$. The $\mathrm{CMD}$ exhibited the $\beta$-type peak at $300^{\circ} \mathrm{C}$, and its peak became a sharp pattern at $350^{\circ} \mathrm{C}$ indicating obviously that $\mathrm{CMD}$ decame $\beta$-type at a lower temperature by about $50^{\circ} \mathrm{C}$ compared with EMD. The difference in those temperatures between the dehydrated

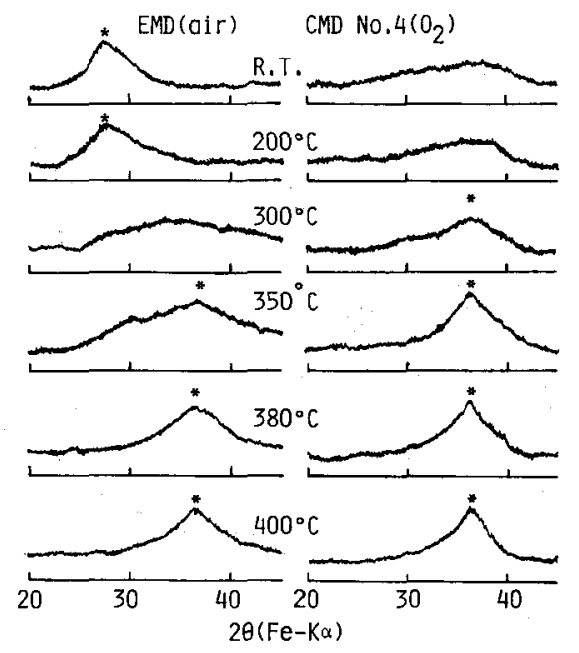

Fig. 8 Effect of the dehydration temperature on $\mathrm{X}$-ray diffraction patterns of both CMD No. 4 and EMD

$*: \gamma$-type peak, $*: \beta$-type peak products of $\mathrm{CMD}$ and EMD might be mainly due to the difference in the residual water content. The dehydration temperature of those materials used in this experiment was higher than that used by Ikeda $e t a l^{12}$. This difference might be attributable to the difference in the conditions of these experiments.

\subsection{Discharge properties}

\subsubsection{The optimum dehydration tempe-} rature for discharge properties and effect of oxygen atmosphere In order to obtain the optimum dehydration temperature for the longest duration time of discharge, discharge tests were perfomed at $0.25 \mathrm{~mA} / \mathrm{cm}^{2}$ on the dehydrated products obtained at various temperatures for both CMD (No. 4 in Table 1) and EMD (No. 7). Figures 9 and 10 show the results of discharge tests at $0.25 \mathrm{~mA} / \mathrm{cm}^{2}$ for both CMD and EMD. The dehydration tem-

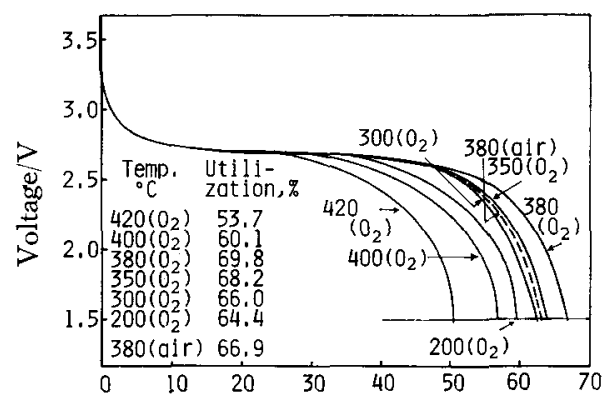

Duration time/h

Fig. 9 Results of $0.25 \mathrm{~mA} \mathrm{~cm}{ }^{-2}$ discharge tests of dehydrated products of No. $4 \mathrm{CMD}$ in both $\mathrm{O}_{2}$ and air atmosphere (Cathode mix : Mix ratio was CMD-1 in Table 2)

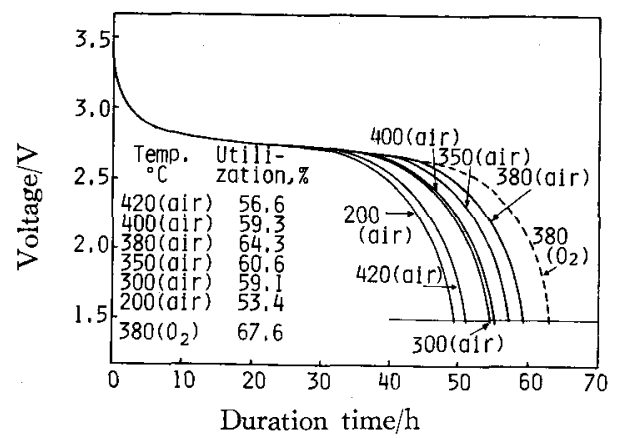

Fig. 10 Results of $0.25 \mathrm{~mA} \mathrm{~cm}$ cm $^{-2}$ discharge tests of dehydrated products of EMD in both air and $\mathrm{O}_{2}$ atmosphere (Cathode mix: Mix ratio was EMD-1 in Table 2) 
perature at which the duration time down to $1.5 \mathrm{~V}$ was the longest was determined as the optimum one. Thus, it was concluded that the considerably longer duration time of discharge was obtained in oxygen.

\subsubsection{The degree of densification and} discharge properties The relation between the $\mathrm{MnO}_{2}$ ratio by the chlorate reaction to total $\mathrm{MnO}_{2}$ and the discharge properties for their dehydrated CMD obtained in oxygen at $380^{\circ} \mathrm{C}$ was investigated. A cathode mix having a standard mixing ratio (CMD-1 in Table 2) was used in this experiment. This result was compared with that for dehydrated EMD as shown in Fig. 11. With increased $\mathrm{MnO}_{2}$ ratio by the chlorate reaction, the duration time was only slightly decreased up to $22 \%$; whereas, it was considerably decreased for more than $23 \%$. It is noted that the dehydrated product of CMD whose $\mathrm{MnO}_{2}$ ratio is $22 \%$ showed a considerably longer duration time compared with that of EMD obtained in both air and oxygen.

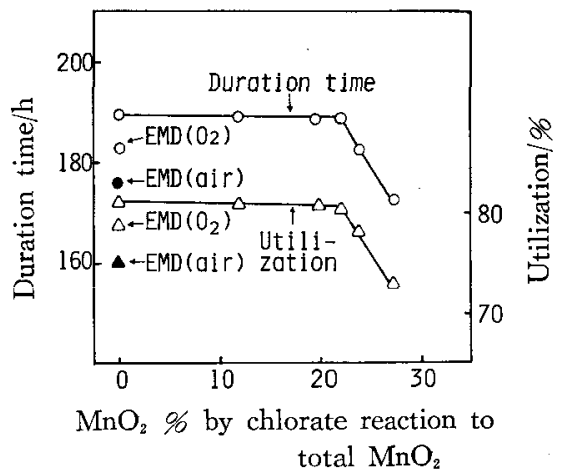

Fig. 11 Relation between $\mathrm{MnO}_{2}$ ratio by chlorate reaction to total $\mathrm{MnO}_{2}$ and performance in 0.1 $\mathrm{mA} / \mathrm{cm}^{2}$ discharge test (Cathode mix : Mix ratio was CMD1 and EMD-1 in Table 2)

3.4.3 Discharge current density, packing capability and the composition of the cathode mix As shown in Fig. 12 for the dehydrated products of both No. 4 CMD obtained in oxygen and EMD (No. 7) obtained in both air and oxygen, respectively, discharge tests at $0.025 \sim 0.5 \mathrm{~mA} / \mathrm{cm}^{2}$ were performed with a cathode mix having both a standard composition and packing quantity. The discha- rge efficiency and duration time increased considerably with decreasing discharge current density. The dehydrated product of No. 4 CMD obtained in oxygen atmosphere was shown to be superior in discharge properties.

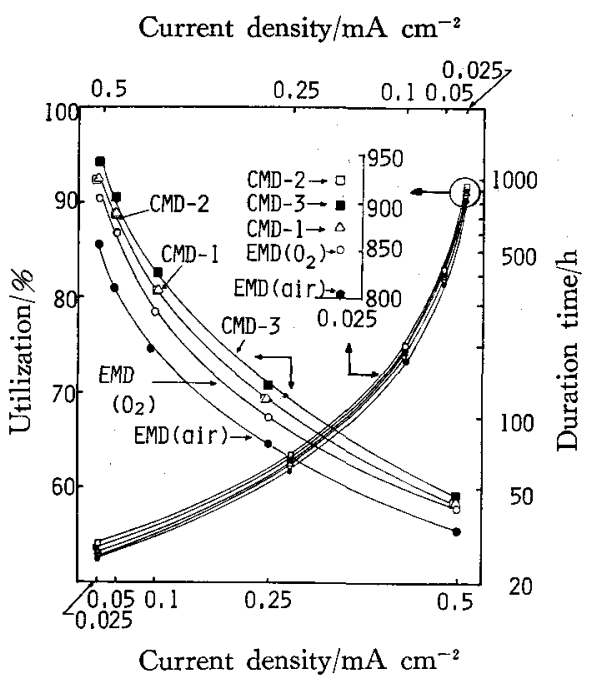

Fig. 12 Relation between current density and discharge performance

The superior packing capability of CMD (No. 4 in Table 1) compared with EMD of standard composition resulted in an increase in packing quantity of the cathode mix with the same thickness compared with dehydrated EMD having the standard packing quantity. This result (CMD-2 in Fig. 12) showed that the discharge efficiency was almost the same as that for the standard composition, the duration time being observed to increase in proportion to the weight of the $\mathrm{MnO}_{2}$ in the cathode mix.

The quantities of both acetylene black and graphite were increased in the cathode mix with the same thickness as that of the dehydrated EMD having the standard packing quantity, with the quantities of $\mathrm{MnO}_{2}$ and Teflon being unchanged. As shown in Fig. 12(CMD-3), it was shown that the increase in quantity of both acetylene black and graphite resulted in increased discharge efficiency, though the duration time did not increase so much as in the case of increased $\mathrm{MnO}_{2}$.

These results led to the conclusion that the dehydrated product of CMD No. 4 obtained in oxygen atmosphere showed a longer duration time than that of EMD in air due to its better 
discharge efficiency and packing capability.

\section{Conclusion}

The heating and dehydration properties in both air and oxygen atmospheres for the densified CMD were compared with those of EMD, and the discharge properties and packing capability of these dehydrated products for $\mathrm{Li}$ $\mathrm{MnO}_{2}$ cells were investigted as follows.

1. In the DTA tests, the peak indicative of conversion to $\mathrm{Mn}_{2} \mathrm{O}_{3}$ shifted to a higher temperature by about $30^{\circ} \mathrm{C}$ in oxygen atmosphere (at $560^{\circ} \mathrm{C}$ ) than in air for both EMD and CMD. For both CMD and EMD, the dehydrated products obtained in oxygen showed a definitely higher $\mathrm{MnO}_{2}$ content and hydrazine index than did those obtained in air, though the effect of the oxygen atmosphere was small. It was considered that the oxygen atmosphere suppressed the decomposition of $\mathrm{MnO}_{2}$ during dehydration.

2. The hydrazine index of the dehydrated CMD was considerably higher than that of EMD at the same dehydration temperature. The hydrazine index of the dehydrated product for CMD showed the same hydrazine index in spite of the increase in the $\mathrm{MnO}_{2}$ ratio by the chlorate reaction when the ratio was less than $22 \%$; whereas, for more than $23 \%$, its value decreased with increasing $\mathrm{MnO}_{2}$ ratio.

3. For both $\mathrm{CMD}$ and EMD, the optimum dehydration temperature was estimated to be about $380^{\circ} \mathrm{C}$ from the discharge properties, and the dehydrated products obtained in oxygen atmosphere were shown to be superior in discharge properties to those of the products obtained in air.

4. The dehydrated CMD whose $\mathrm{MnO}_{2}$ ratio by the chlorate reaction was $22 \%$ showed excellent packing capability and discharge properties compared with those of EMD as the cathode material in $\mathrm{Li}-\mathrm{MnO}_{2}$ cells.

\section{References:}

1) Hironosuke Ikeda, Toshihiko Saito and Hideo Tamura, Manganese Dioxide Symposium, Vol. 1, 384 (1975), Cleveland.

2) Taketsugu Hirai and Isao Tari, Progress in Batteries and Solar Cells, Vol. 3, 15 ? (1980).

3) Kazuhide Miyazaki, Manganese Dioxide Symposium, Vol. 1, (1975), Cleveland.

4) Isao Tanabe, Ryoichi Nagata, Toru Watanabe and Nobuaki Miyamoto, Denki Kagaku 49, 192 (1981).

5) Isao Tanabe, Nobuaki Miyamoto, Ryoichi Nagata and Toru Watanabe, Denki Kagaku 49, 175 (1981).

6) Isao Tanabe, Ryoichi Nagata, Nobuaki Miyamoto and Toru Watanabe, Denki Kagaku 49, 766 (1981).

7) C. Drotschmann, Moderne Primärbatterien, Nikolaus Barnz, Berlin-Schöneberg, s. 133 (1951).

(Received Aug. 14, 1981; Accepted Jan. 29, 1982)

\title{
基 礎 電 気 化 学 測 定 法
}

\section{会誌揭載講義シリーズ合本 電気化学協会編 B 5 判 72 ページ 領布価 1,200 円（送料 300 円）}

论内 容 ○基淮電極-水溶液用基蕉電極（大滝仁志，前田益伸） ○基淮電極一非水溶液用基淮電極（伊豆津公佐，中村俊夫）

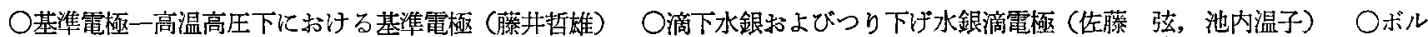
タンメトリー用指示電極としての固体電極（佐櫒祐一，高村 魅） ○溶媒と電解質（伊豆津公佑）○ポテンシォスタットとガ ルバノスタット一動作原理と使用上の問題点（高橋勝緒）○測定用機器, 沉用機器の原理々使い方（高橋勝緒, 松田 清） ○研 究者フォイルとラボラトリーコンピュータシステム (山田明文, 加藤良清)

\section{電気化学測定法一一基礎理論および測定回路編}

\author{
会誌揭載譵義シリーズ合本 電気化学協会編 B 5 判 98 ページ 頒布洒 1,200 円 (送料 300 円)

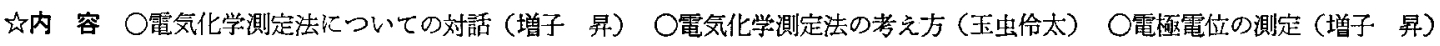

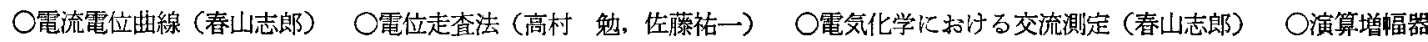 \\ の使い方・兑らび方（仁木克己） ○ステップ入力信号に対する電極系の応答（仁木克己，高橋正雄） ○ポーラログラフ装置（竹 \\ 盛欣男。松田 清) ○電流パルス実験法 (神猗 愷, 青柳 茂) \\ 申込先 100 東京都干代田区有楽町 1-12-1 新有楽町ビル 電気化学協会 (8 03-214-6001，6002).
}

